\title{
Trade Liberalization, Energy-Saving Technological Change and Energy \\ Intensity: Some empirical evidence from China
}

\author{
Jun Wang Chengbo Wang Xuan Wan
}

\begin{abstract}
This paper discusses the transmission mechanism and effects that trade liberalization influences energy intensity through energy-saving technological change (ESTC). We construct panel data from manufacturing industries in China over the period of 1994-2017, thereby conducting empirical tests through mediation models and discontinuity regression models. The results find that trade liberalization significantly promotes the lowering of energy intensity through ESTC. Heterogeneity test results show that the trade liberalization effect is higher in industries with low barriers to entry and industries with high-pollution. Fuzzy Regression Discontinuity (FRD) results show that energy intensity decreasing as China's accession to the WTO.
\end{abstract}

Keywords: Trade liberalization; Energy-saving technological change; Energy intensity JEL Classification: F10; F18; L60; Q43

\section{Introduction}

Since 1990s', China has implemented trade liberalization reforms that primarily reduce tariffs and lower non-tariff barriers. After joining in the WTO, China's simple average tariff rate fell drastically from $17.4 \%$ in 2000 to $9.8 \%$ in 2017 , a rate lower than the average tariff rate of the developing countries ${ }^{1}$. During this period, China's import, export trade and FDI grew rapidly. From 2001 to 2017 , China's export trading volume grew by nearly sevenfold, from $\$ 266$ billion to $\$ 2.263$ trillion, making it the largest export trading country in the world. China's imports grew by an average of $13.5 \%$, twice as fast as world imports ${ }^{2}$. The World Investment Report (2019) shows that the total amount of FDI attracted by China rose by 4 percent to US \$139 billion in 2018, remaining firmly the second largest foreign investment inflow country in the world.

While trade liberalization has decreased trading costs, promoted the expansion of production capacity and trade growth, it has also resulted in a surge in energy consumption (Mitchener and Yan, 2010; Anwar and Sun, 2012). According to the data from the BP Statistical Review of World Energy, China was the largest energy-consuming country in the world in 2016 , accounting for $23 \%$ of the world's energy consumption and $27 \%$ of the growth in global energy consumption. Moreover, China's coal consumption volume has reached 26 million tons of oil equivalents, and petroleum consumption has also demonstrated a large growth, with daily consumption volume increased by 400,000 barrels. In 2018, China's petroleum consumption increased by an average of 680,000 barrels per day, making it the fastest growing country in the world.

Trade liberalization has undoubtedly driven the expansion of production capacity, which has

\footnotetext{
(1) Tariff data comes from the WTO tariff database.

(2) Import trade and export trade data come from the annual China Statistical Yearbook and WTO database.
} 
in turn promoted the growth of energy consumption. Some scholars have found that trade liberalization promotes energy consumption, based on national, industry and enterprises level data (Ghani, 2012; Koengkan, 2018). We are concerned with whether trade liberalization would result in lowered energy intensity. Because lowered energy intensity occurs concomitantly with increased energy efficiency, this ensures the realization of energy conservation and emission reduction, as well as protection of the ecological system. Figure 1 reflects the increases of China's energy consumption from 1980 to 2017. Figure 2 illustrates the declining trend of energy intensity in China (1990-2015). At the same time, compared with the global average energy intensity, energy intensity in China has a large downward trend.

We will discuss the functional mechanisms and effects of trade liberalization on China's energy intensity (Grossman and Krueger 1995; Cole and Elliott 2003; Rafiq et al., 2016). If trade liberalization was proved to promote a decrease in China's energy intensity, it would provide new support for China as the country further implements trade liberalization strategies. Conversely, if trade liberalization drives an increase in energy intensity, a solution to lower energy intensity needs to be found. And China needs to reconsider foreign trade policies for the coordination between energy policies and trade policies.

Some literature has pointed that technological progress plays a leading role in slowing pollution emissions and reducing energy intensity (Popp, 2002; Karanfil and Tamsamani. 2010; Wang, 2020). The paper tries to answer whether trade liberalization affects energy intensity through energy-saving technological change (ESTC). In the case of given output, energy inputs will be reduced in the production process ${ }^{\circledR}$. So, ESTC plays a key role in reducing energy intensity.

The paper constructs both mediation model and fuzzy regression discontinuity (FRD), using 1994-2017 panel data from 27 manufacturing industries in China. The results find that trade liberalization significantly promotes the lowering of energy intensity through ESTC. Heterogeneity test results show that the trade liberalization effect is higher in industries with low barriers to entry and industries with high-pollution. China's entry into the WTO provides an institutional breakpoint. Fuzzy regression discontinuity (FRD) results show that energy intensity decreasing as China's accession to the WTO.

Based on the previous studies, the novel aspects of this paper include the following areas: First, this paper discusses the influencing mechanisms of trade liberalization on energy intensity. To do so, a mediation model is constructed that examines the transmission mechanism of energy intensity affected by trade liberalization through ESTC. Second, this paper goes beyond simply studying the average effects of trade liberalization on energy intensity changes. We also examine the industrial heterogeneity of trade liberalization affecting energy intensity. Third, China has begun to drastically reduce tariff and non-tariff barriers after having joined the WTO. The paper adopts Fuzzy Regression Discontinuity (FRD) to investigate the energy intensity effects as China's accession to the WTO.

\footnotetext{
(3) The industries with high degree of market opening are facing fierce market competition, which promotes the adoption of energy-saving technologies, thus resulting in ESTC. We take the wood processing industry as an example. The energy consumption of wood drying accounts for $40 \%-70 \%$ of the total energy consumption of wood processing. At present, solar energy storage technology is widely used in this industry to improve the heat utilization ratio of the whole heating system by using the heat energy or waste heat in the heating process. The application of new energy-saving technology reduces the energy consumption of wood drying and shows ESTC obviously. This example is also consistent with the ESTC results calculated in this paper.
} 


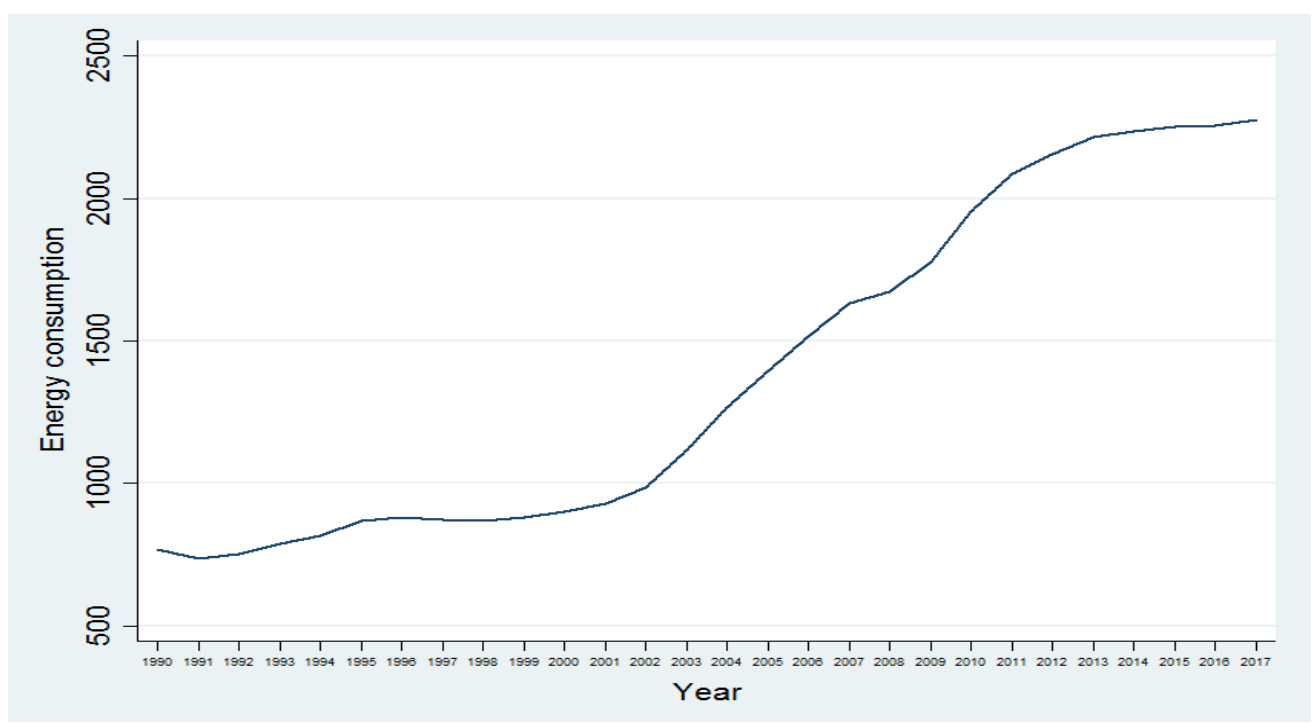

Fig1. Energy Consumption Treads in China (Ten thousand of standard coal).

(Data sources: World Bank database)

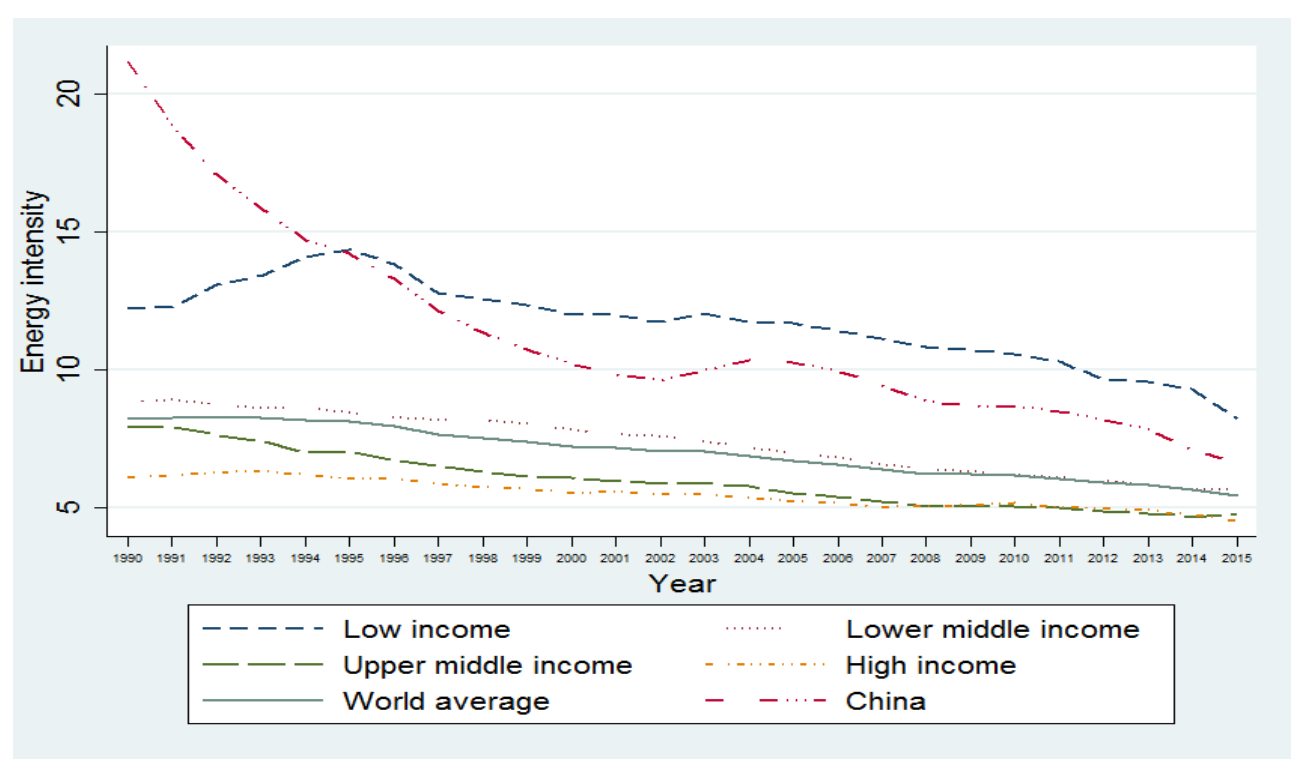

Fig 2. Energy Intensity Treads in the world (MJ/\$2011 PPP GDP)

(Data sources: World Bank database)

\section{Literature Review}

A number of recent studies have investigated the impact of trade liberalization on energy consumption, energy efficiency and pollution emissions (Managi et al., 2009; Hossain, 2011; Shafiei and Salim, 2014; Kasman and Duman, 2015). In the literature, two lines of thought have emerged about the impact of trade liberalization on the energy consumption. The researchers with the thoughts of the first stream argue that trade liberalization increases the consumption of energy. For instance, Cole (2006) using World Bank data, Gumilang et al. (2011) studying on Indonesia data and Alessandrini et al. (2011) studying on India data find that trade liberalization promotes energy consumption growth. Sadorsky (2011) identifies that trade liberalization promotes energy 
consumption growth in the short and long run in a sample of 8 Middle Eastern countries over the period of 1980-2007. Nasreen and Anwar (2014) find a positive bidirectional relationship between trade liberalization and energy consumption based on 15 Asian countries in 1980-2011. Koengkan (2018) demonstrates that trade liberalization have a positive effect on energy consumption in a sample of four Andean community countries over the period of 1971-2014. However, the researchers with second stream thoughts suggest that trade liberalization decreases the energy consumption. For example, Sbia et al. (2014) investigate the United Arab Emirates (UEA), Shahbaz et al. (2013) investigate Indonesia and find that trade liberalization reduces the consumption of energy. Hübler and Keller (2010) find that it is not possible to robustly conclude whether energy consumption decreases or increases because of the FDI inflows arising from trade liberalization on developing countries. Ghani (2012) contend that trade liberalization has different degrees of influence on the energy consumption in the developed and developing countries. Trade liberalization results in the growth of energy consumption among developing countries, whereas it promotes lowering energy consumption and energy intensity in the developed countries.

Scholars have also studied the mechanism of trade liberalization affecting the energy intensity. Grossman and Krueger (1995) firstly proposed "size, technology, and structure" analysis framework to study the environmental effects of trade liberalization. Cole and Elliott (2003) as well as Cole (2006) then apply this analytical paradigm to study the effect of trade liberalization on energy consumption, namely studying the mechanisms that trade liberalization influences energy consumption through market size, industrial structure, and technological change. They find that trade liberalization promotes the expansion of market size, causing an increase in energy consumption, whereas technological change resulting in lowered energy consumption. Besides, the structure effect of trade liberalization refers to energy consumption changes determined by industrial structure changes. If trade liberalization results in the transfer or elimination of energy-intensive industries, then energy consumption will be reduced. Otherwise, trade liberalization may result in higher energy consumption. In this analytical framework, many scholars have used data from different countries and regions to perform empirical tests. Early literature includes the following: Copeland and Taylor (2004), Perkins and Neumayer (2005), Stern (2007). Some Chinese scholars have embarked on relevant studies in recent years. Zhang (2009) constructs an input-output table in China from 1987 to 2006 to study the effects of the opening up of trade on Chinese energy consumption. The study find that the market size effect promoting growth in energy consumption, whereas technological changes lowering energy consumption. Xu and Yin (2016) analysis the relationship between the degree of trading openness and energy consumption of various provinces, find that the greater the trade openness, the higher the energy efficiency under the condition that the size effect is less than the combined technological effect and structure effect.

Scholars have recognized the important role of technological change in reducing energy consumption. However, technological change is only regarded as changes in general total factor productivity (TFP), or changes in emission specific technology. They fail to consider the impact of ESTC on energy consumption (Ghirmay et al. 2001; Copeland and Taylor 2003). If trade liberalization results in ESTC, it will decrease energy consumption by relatively increasing energy efficiency and energy marginal productivity. Conversely, energy-augment technological change will increase energy consumption (Acemoglu, 2002). As such, ESTC is the core variable to explain lowered energy consumption.

In addition, most studies focused on the relationship between trade liberalization and energy 
consumption rather than energy intensity. The most recent study involving trade liberalization and energy intensity is based on the following literature. Managi et al. (2009) investigate the impact of trade openness on environmental degradation in OECD countries in a period of 1971 to 1996. The empirical evidences point that the trade openness improves the environmental quality in OECD countries, because of reducing the energy consumption and energy intensity from fossil fuels. Rafiq et al. (2016) investigate the impact of both urbanization and trade liberalization on emissions and energy intensity for twenty-two emerging economies by using contemporary panel data. They find that trade liberalization significantly reduces both pollutant emissions and energy intensity, whereas urbanization significantly increases energy intensity.

The existing literature does not examine the existence of ESTC in China's industrial sector. Does trade liberalization affect energy intensity through ESTC? This paper studies the effect of trade liberalization on energy intensity through ESTC. The research focuses on both the direct impact and the transmission mechanism.

\section{Empirical design}

\subsection{Empirical Models}

To study whether trade liberalization influences energy intensity through ESTC, the mediation model will be used to identify the transmission paths. The following three regression equations are constructed:

$$
\begin{gathered}
E I_{i t}=\beta_{0}+\beta_{1} \text { Tariff }_{i t}+X_{i t} \beta+\eta_{i}+\varphi_{t}+\varepsilon_{i t} \\
E_{S T C}=\alpha_{0}+\alpha_{1} \text { Tariff }_{i t}+X_{i t} \alpha+\kappa_{i}+\phi_{t}+\xi_{i t} \\
E I_{i t}=\theta_{0}+\theta_{1} \text { Tariff }_{i t}+\theta_{2} \text { ESTC }_{i t}+X_{i t} \theta+\gamma_{i}+\mu_{t}+\zeta_{i t}
\end{gathered}
$$

In this equation, $E I_{i t}$ represents the energy intensity of industry $\mathrm{i}$ during period $\mathrm{t}$, which is represented as the ratio of the energy consumption volume to the total industrial sales. Tariff it is the trade liberalization represented by the tariffs of industry i. ESTC ${ }_{i t}$ represents the mediation variables (ESTC). X is the control variable. $\eta_{i}, \kappa_{i}, \gamma_{i}$ are the fixed industry effect, $\varphi_{t}, \phi_{t}, \mu_{t}$ are the fixed time effect, and $\varepsilon_{i t}, \xi_{i t}, \zeta_{i t}$ are the random error term.

The first step is to estimate the model (1). If $\beta_{1}$ is significantly positive, trade liberalization promotes decrease in energy intensity. The second step is to estimate the model (2) and examine the relationship between trade liberalization and mediation variables. Finally, the model (3) is estimated. When $\alpha_{1}, \theta_{2}$ are significant and $\theta_{1}$ is not significant, there is a complete mediating effect. If $\theta_{1}$ is significant, there is a partial mediating effect. The effect of trade liberalization on energy intensity is only partially achieved through the mediation variables (ESTC).

At the end of 2001, China began to drastically reduce tariff and non-tariff barriers, and trade liberalization level has greatly increased because of joining the WTO. China's entry into the WTO 
provides an institutional breakpoint. In this way, the exogenous institutional breakpoint distributes samples to both sides of the breakpoint according to a pre-determined rule, thus creating the effect of natural experimentation. Regression discontinuity (RD) can be used to evaluate the impact of trade liberalization. $\mathrm{RD}$ can be divided into sharp regression discontinuity (SRD) and fuzzy regression discontinuity (FRD). In order to fulfill the commitments of China's accession to the WTO, tariff reduction shall be implemented in different sectors and stages. Moreover, not all industries will be affected by the "free trade policy" at the same time after joining the WTO. Therefore, not all industries will enter the treatment group after 2002. Therefore, the paper intends to adopt Fuzzy Regression Discontinuity (FRD) to investigate the energy intensity effects as China's accession to the WTO (which is a non-continuity policy).

\subsection{Variable Design}

1. Trade liberalization (Tariff)

Trade liberalization includes lowered tariffs and the reduction of various non-tariff barriers. The non-tariff barriers are used to measure the degree of trade liberalization in the robustness test. Import input tariffs are adopted as the measure of trade liberalization in the test. Input tariffs describe the average tariffs on inputs required for production in various industries. As each industry may import a wide variety of products, import input tariffs are more representative of the trade liberalization level than those on output tariffs. Since the UNCTAD database provides import output tariff data of HS 6-digit code production, it is necessary to convert the output tariff into the input tariff. According to the methodology of Amiti and Konings (2007), the input tariffs are the weighted average of the output tariffs. The input tariffs for of industry $i$ of year $t$ are represented as:

$$
\text { Tariff } f_{\text {it }}=\sum_{g} \alpha_{g i} * \text { Outputtarif } f_{g t}
$$

In this equation, $a_{g i}$ (coefficient of input-output matrix) represents the cost share of $g$ industry

products in the production of $\mathrm{i}$ industry products, that is, $\alpha_{g i}=\frac{\text { Input }_{g i}}{\sum_{g} \text { Input }_{g i}}$, Outputtariff $f_{g t}$ is the output tariff.

\section{Energy-saving technological change (ESTC)}

Most scholars use indirect estimation methods to measure the factor-biased technological change. For example, Michaels et al. (2010) indirectly measures capital-augment technological change with computer penetration rate and information capital rate. Caselli (2014) measures skillbiased technological change with industry-level machine equipment price. The paper directly measures the index of ESTC based on cost function.

This paper establishes a production system composed of n factors, $y=f\left(x_{1}, \cdots x_{n}, t\right)$. Where $x_{j}(j=1, \cdots n)$ represents the input quantity of the factor $\mathrm{j}$, and $\mathrm{t}$ represents technological change. Using the duality theorem, the cost equation containing non-neutral technological change is $C=g\left(p_{1}, \cdots p_{n}, y, t\right)$, where $p_{j}(j=1, \cdots n)$ represents the price of factor $\mathrm{j}$. Without prior constraints, various specific forms of equations can be established. The paper establishes the transcendental logarithmic cost equation: 


$$
\begin{gathered}
\ln C_{t}^{i}=\rho_{0}^{i}+\sum_{j} \rho_{j}^{i} \ln p_{j}^{i}+\frac{1}{2} \sum_{j} \sum_{j^{\prime}} \rho_{j j^{\prime}}^{i} \ln p_{j}^{i} \ln p_{j^{\prime}}^{i}+\sum_{j=1} \rho_{j y}^{i} \ln y^{i} \ln p_{j}^{i}+ \\
\sum_{j} \rho_{j t}^{i}{ }_{j t} \ln p_{j}^{i}+\rho_{y}^{i} \ln y^{i}+\frac{1}{2} \rho_{y y}^{i}\left(\ln y^{i}\right)^{2}+\rho_{y t}^{i} \ln y^{i}+\rho_{t}^{i} t+\frac{1}{2} \rho_{t}^{i} t^{2}
\end{gathered}
$$

The paper assumes that the final production section (i) requires four factors (j): capital (K), labor (L), energy (E), and intermediate products (M). The cost equation $C(p, Y, t)$ depends on the factor price, output level, and time variables. The cost equation is constructed as the translog cost equation: $j, j^{\prime}=K, L, E, M, C$ is production cost, $p_{j}, p_{j^{\prime}}$ stands for factor price. Factor share equation $S_{j}$ :

$$
S_{j}^{i}=\rho_{j}^{i}+\sum_{j} \rho_{j}^{i} \ln p_{j}^{i}+\rho_{j}^{i} t+\vartheta_{i}
$$

If $\rho_{j}^{i}=0$, technological change is neutral; $\rho_{j}^{i} \neq 0$, technological change is biased (among them, $\rho_{j}^{i}<0$ means factor-saving technological change, $\rho_{j}^{i}>0$ means factor-augment technological change).

Without loss of generality, model (7) satisfies the following constraints: (1) homogeneity:

$$
\sum_{j} \rho_{j}^{i}=1 ; \sum_{j^{\prime}} \rho_{j j^{\prime}}^{i}=\sum_{j} \rho_{j y}^{i}=\sum_{j} \rho_{j t}^{i}=0 ; \text { (2) symmetry: } \rho_{j j^{\prime}}^{i}=\rho_{j^{\prime} j}^{i}, \rho_{j y}^{i}=\rho_{y j}^{i} \text {; }
$$

(3) monotony: $\frac{\partial \ln C_{t}^{i}}{\partial \ln p_{j}^{i}}=S_{j}^{i} \geq 0$; (4) local concavity.

In this paper, technological progress is regarded as a dynamic process, that is, it changes with time. The invariant time trend variable in (6) is replaced by an unobservable variable (latent variable) in a state space model. The non-observable latent variable is estimated by the Kalman Filter method:

$$
\begin{aligned}
& Z_{t}^{j}=C^{j} Z_{t-1}^{j}+\theta_{t}^{j} \\
& Y_{t}=A^{j} X_{t}^{j}+Z_{t}^{j}+\varepsilon_{t}^{j}
\end{aligned}
$$

With: $\left[\begin{array}{c}\mu_{t}^{j} \\ w_{t}^{j}\end{array}\right] \sim I N D\left[\begin{array}{cc}0 & Q^{j} \\ 0 & \lambda^{j} Q^{j}\end{array}\right] ; \quad \lambda^{j}=R^{j} / Q^{j}$

$Y_{t}, X_{t}$ are the vector forms of observed, explanatory variables. $Z_{t}$ is the vector forms of latent variable. Both $\mathrm{A}$ and $\mathrm{C}$ represent constant matrices, $\theta_{t}$ and $\varepsilon_{t}$ are the Gaussian independent disturbance with $\mathrm{R}$ and $\mathrm{Q}$ as covariance matrices. $\lambda$ is a diagonal matrix. The (6) formula is converted to the following state-space model: 


$$
\begin{aligned}
Y_{t} & =\left(\begin{array}{c}
S_{K t} \\
S_{L t} \\
S_{E t}
\end{array}\right) ; X_{t}=\left(\begin{array}{c}
1 \\
\ln p_{k t}-\ln p_{M t} \\
\ln p_{L t}-\ln p_{M t} \\
\ln p_{E t}-\ln p_{M t} \\
\ln y_{t}
\end{array}\right) ; Z_{t}=\left(\begin{array}{c}
\rho_{K t} \\
\rho_{L t} \\
\rho_{E t}
\end{array}\right) \\
A & =\left(\begin{array}{cccc}
\rho_{K} & \rho_{K K} & \rho_{L K} & \rho_{K Y} \\
\rho_{L} & \rho_{K L} & \rho_{L L} & \rho_{L Y} \\
\rho_{E} & \rho_{K E} & \rho_{L E} & \rho_{E Y}
\end{array}\right) ; C=\left(\begin{array}{ccc}
1 & 0 & 0 \\
0 & 1 & 0 \\
0 & 0 & 1
\end{array}\right) \\
Q & =\left(\begin{array}{ccc}
\operatorname{var}\left(\varepsilon_{t}^{K}\right) & 0 & 0 \\
0 & \operatorname{var}\left(\varepsilon_{t}^{L}\right) & 0 \\
0 & 0 & \operatorname{var}\left(\varepsilon_{t}^{E}\right)
\end{array}\right) ; R=\left(\begin{array}{ccc}
\operatorname{var}\left(\theta_{t}^{K}\right) & 0 & 0 \\
0 & \operatorname{var}\left(\theta_{t}^{L}\right) & 0 \\
0 & 0 & \operatorname{var}\left(\theta_{t}^{E}\right)
\end{array}\right)
\end{aligned}
$$

Kalman filtering includes filtering stage and smoothing stage. The unknown variable $\left(\rho_{j t}\right)$ can be estimated using MLE (Maximum Likelihood Estimation) and recursive method respectively. $\rho_{E t}<0$ means energy-saving technological change (ESTC), and $\rho_{E t}>0$ means energy-augment technological change.

Table 1 reports the result of ESTC. The results show that most of the industries in China have energy-saving technological change except 1 industries (oil processing industry). The average value of ESTC is -0.0512, which reflects the overall existence of ESTC in China. Among them, paper products industry, wood processing industry, Chemical materials and food manufacturing industry have the highest ESTC. These industries are raw materials-intensive industries, using more raw materials and relatively less energy in production. Energy intensity is relatively low in these industries. ESTC of communication equipment industry and general equipment industry are relatively small, the average value is near 0 . These industries are generally energy-intensive industries and may require more energy input in the production process. Energy efficiency is relatively lower than other factors.

Table1. The result of ESTC

\begin{tabular}{c|c|c|c|c|c}
\hline industry & ESTC & industry & ESTC & industry & ESTC \\
\hline Food manufacturing & -0.1345 & Pharmaceutical manufacturing & -0.1001 & Oil processing & 0.1235 \\
Beverage manufacturing & -0.0736 & Plastic products & -0.0412 & Chemical materials & -0.1408 \\
Tobacco processing & -0.0355 & Metal products & -0.0013 & Chemical fiber & -0.0196 \\
The textile industry & -0.0414 & General equipment & -0.0009 & Rubber products & -0.0503 \\
Clothing, shoes and hats & -0.0158 & Special equipment & -0.0513 & Nonmetallic mineral & -0.0871 \\
Leather hairiness & -0.0361 & Transportation equipment & -0.0445 & Black metal & -0.0333 \\
Wood processing & -0.1429 & Electrical machinery & -0.0274 & Nonferrous metal & -0.0595 \\
Furniture manufacturing & -0.0516 & Communication equipment & -0.0004 & & \\
printing industry & -0.1104 & Instrument and meter & -0.0112 & & \\
Cultural and educational & -0.0113 & Paper products & -0.1846 & & \\
supplies & & & & & \\
\hline
\end{tabular}




\section{Control variables}

To improve the reliability of the estimated results, control variables were added: (1) Market size (Scale): It is represented as the added value of various industries, which is then processed logarithmically. (2) Factor structure (KL): It is represented as the capital-labor ratio, which is then processed logarithmically. (3) Environment regulatory intensity (ERI): It is represented as the ratio of the wastewater management fees to the added value of various industries. Environmental regulation will increase the operating cost of polluting enterprises, which will encourage enterprises to accelerate technological innovation and reduce energy intensity. (4) Foreign direct investment (FDI): FDI promotes domestic enterprises to improve technology and reduce energy consumption through technological spillovers and learning effects. So it is represented as the ratio of FDI to the industrial added value of various industries. (5) Ownership structure (OS): It is represented as the ratio of state capital to the industry owner's equity of various industries. Different ownership structure is very different from management mode and incentive mechanism, and it also has a significant impact on energy efficiency.

\subsection{Data}

This paper uses samples from the sub-sectors of 27 manufacturing industries over the period of 1994-2017. The import tariff data for HS6-digit code products are taken from the WTO database (i.e. Tariff Download Facility). According to the conversion tables (HS1996 and HS2002, HS2007 and HS2002, HS2012 and HS2002) provided by the United Nations, tariffs data for different years are unified into HS2002. According to the conversion relationship between HS2002 and GB / T2002, the industry level tariff can be calculated by using the product level tariffs data of HS2002.

The relevant variables are explained as follows for the estimation of ESTC:1 The Capital Price $\left(p_{k}\right)$ is selected as the fixed assets investment price index in each year. (2) The labor price $\left(p_{L}\right)$ is expressed as the average wage index of each industry. (3) Energy prices $\left(p_{E}\right)$. Because each industry's energy consumption is measured in standard coal, the price of coal represents the energy price. (4) capital stock (K). This paper uses perpetual inventory method to estimate the capital stock, and convert the fixed assets investment into capital stock in each year. (5) The number of labor (L) is expressed by the number of employed persons at the end of the year in each industry, and the total labor cost is expressed by the total amount of actual wages in each industry. (6) energy consumption (E) is the amount of energy consumption in each industry.

The above data are taken from China Statistical Yearbook, China Labor Statistical Yearbook, China Energy Statistical Yearbook, and China Price Yearbook. The data of ERI in the control variables were obtained from China Environmental Statistical Yearbook. The other data in the control variables were calculated from the relevant data in China Statistical Yearbook. Table 2 presents the descriptive statistics of the major variables.

Table2. Descriptive Statistics

\begin{tabular}{c|c|c|c|c|c}
\hline Variable & Definition & Mean & $\begin{array}{c}\text { Standard } \\
\text { deviation }\end{array}$ & Min & Max \\
\hline Tariff & The input tariffs for of industry & 0.0484 & 0.0216 & 0.0076 & 0.1318 \\
\hline ESTC & Energy-saving technological change & -0.0512 & 0.0601 & -0.1846 & 0.1235 \\
\hline EI & the energy intensity of industry & 0.0172 & 0.0250 & 0.0006 & 0.1535 \\
\hline
\end{tabular}




\begin{tabular}{c|c|c|c|c|c}
\hline Scale & $\begin{array}{c}\text { the added value of industry and take the } \\
\text { logarithm }\end{array}$ & 8.5949 & 1.3709 & 5.3881 & 11.5202 \\
\hline KL & $\begin{array}{c}\text { the capital-labor ratio of industry and take } \\
\text { the logarithm }\end{array}$ & 3.0062 & 1.5692 & 0.3745 & 6.1014 \\
\hline ERI & $\begin{array}{c}\text { the ratio of the wastewater management } \\
\text { fees to the added value of various } \\
\text { industries }\end{array}$ & 0.0052 & 0.0114 & 1.72971 & 4.9260 \\
\hline FDI & $\begin{array}{c}\text { the ratio of FDI to the industrial added } \\
\text { value of industry }\end{array}$ & 0.1771 & 0.0967 & 0.000023 & 0.4923 \\
\hline OS & $\begin{array}{c}\text { the ratio of state capital to the industry } \\
\text { owner's equity of industry }\end{array}$ & 0.0709 & 0.0823 & 0.000028 & 0.5971 \\
\hline
\end{tabular}

\section{Analysis of Empirical Findings}

\subsection{Benchmark Regression}

Table 3 shows the regression results based on the mediation model (1)-(3). Columns (1) to (3) of Table 3 are estimation results that do not contain double fixed effect, Columns (4) to (6) are estimated results that contain industry fixed effect and time fixed effect. The estimated trade liberalization parameter values are 0.3203 and 1.7508 based on the model (1). If tariff is reduced by 1 unit, energy intensity will be reduced by $32.02 \%$ and $175.08 \%$, respectively. The result shows that there is a significantly positive relationship between tariff and energy intensity. In other words, reduced tariff rates and increased trade liberalization promotes a reduction in energy intensity. Next, the paper examines the relationship between trade liberalization and ESTC based on model (2). The results show that trade liberalization is beneficial to strengthening energy-saving technological change ${ }^{\oplus}$. Columns (3) and (6) report the estimated results according to model (3). The parameter values of trade liberalization are 0.2777 and 1.6213, which decreases relative to Columns (1) and (4). According to the judgment method of the mediation model, it can be concluded that trade liberalization lowers energy intensity through energy-saving technological change.

The estimation results of control variables mostly accord with the theoretical expectation. For instance, Market size (Scale) promotes the declining of energy intensity. With the increase of capitallabor ratio (KL), FDI and environmental regulation index (ERI), it helps to reduce energy intensity. The proportion of state-owned (OS) is positively correlated with energy intensity.

Table3. Estimation results of benchmark regression

\begin{tabular}{ccccccc}
\hline & EI & ESTC & EI & EI & ESTC & EI \\
\cline { 2 - 6 } & $(1)$ & $(2)$ & $(3)$ & $(4)$ & $(5)$ & $(6)$ \\
\hline \multirow{2}{*}{ Tariff } & $0.3203 * * *$ & $0.2694 * *$ & $0.2777 * *$ & $1.7508 * * *$ & $0.5092 * *$ & $1.6213 * *$ \\
& $(2.83)$ & $(2.23)$ & $(2.04)$ & $(2.71)$ & $(2.28)$ & $(2.27)$ \\
ESTC & & $0.1683 * * *$ & & $0.5793 * *$ \\
& & & $(5.95)$ & & $(2.09)$ \\
lnScale & $-0.2231^{* * *}$ & $-0.0004 * * *$ & $-0.2312^{* * *}$ & $-0.3522 * * *$ & $-0.0066^{* * *}$ & $-0.3483 * * *$ \\
& $(-8.34)$ & $(-3.11)$ & $(-8.96)$ & $(-4.75)$ & $(-2.51)$ & $(-4.72)$ \\
KL & $-0.0049^{* * *}$ & $-0.0002 * *$ & $-0.0040^{* * *}$ & $-0.0039 * * *$ & $-0.0001 * * *$ & $-0.0038^{* * *}$
\end{tabular}

\footnotetext{
(4) The part of estimated results is not reported.
} 


\begin{tabular}{ccccccc} 
& $(-4.17)$ & $(-2.26)$ & $(-3.52)$ & $(-3.46)$ & $(-2.87)$ & $(-3.38)$ \\
ERI & $-0.0001^{*}$ & $-0.0007^{*}$ & $-0.0001^{* *}$ & $-0.0003^{* * *}$ & $-0.0001^{* * *}$ & $-0.0003^{* * *}$ \\
& $(-1.84)$ & $(-1.81)$ & $(-2.22)$ & $(-7.61)$ & $(-2.54)$ & $(-7.69)$ \\
FDI & $-2.4835^{* * *}$ & $-0.0204^{* * *}$ & $-2.5141^{* * *}$ & $-1.0364^{*}$ & $-0.0088^{* *}$ & $-1.0415^{* *}$ \\
& $(-6.39)$ & $(-3.03)$ & $(-6.71)$ & $(-1.97)$ & $(-2.09)$ & $(-1.98)$ \\
OS & $0.6603^{* *}$ & 0.0106 & $0.6032^{*}$ & $0.3125^{*}$ & 0.0017 & 0.3115 \\
& $(2.02)$ & $(0.24)$ & $(1.92)$ & $(1.91)$ & $(0.87)$ & $(1.41)$ \\
Industry fixed & No & No & No & Yes & Yes & Yes \\
effect & & & & & & Yes \\
Time fixed & No & No & No & Yes & Yes \\
effect & & & & & & \\
Observations & 486 & 486 & 486 & 486 & 486 & 486 \\
R-squared & 0.5279 & 0.4597 & 0.5335 & 0.8658 & 0.8932 & 0.8811 \\
\hline
\end{tabular}

Note: $(1) * * * p<0.01, * * p<0.05$, and $* \mathrm{p}<0.1$; (2) $\mathrm{t}$-values are reported in parentheses. (3)Indirect effect is 0.0453 , direct effect is 0.2777 , and total effect is 0.323 , according to the regression results in Columns (1) to (3). Indirect effect is 0.2950 , direct effect is 1.6213 , and total effect is 1.9163 , according to the regression results in Columns (4) to (6).

\subsection{Heterogeneity Testing}

In this section, we will carry out heterogeneity testing. We divide samples into high entry barrier industries and low entry barrier industries, or into high pollution industries and low pollution industries. In reality, when market barriers to entry are low, trade liberalization intensifies market competition and promotes technological innovations, thereby lowering energy intensity. Conversely, when market barriers to entry are high, the effects from the technological innovations of trade liberalization are limited. To verify this opinion, this paper performs heterogeneity testing on the transmission paths of trade liberalization based on relative barriers to entry. Meanwhile, this paper uses industry ownership structures as a basis to categorize the barriers to entry. If the proportion of state capital for the industry is higher than the average proportion of state capital for all industries, the industry is defined as one with high barriers to entry. ${ }^{(5)}$ Otherwise, the industry is recognized as one with low barriers to entry. Twelve industries had high barriers to entry: tobacco, printing, petroleum processing, coking and nuclear fuel processing, chemical materials and chemical product manufacturing, chemical fiber manufacturing, rubber product manufacturing, non-metal mineral product manufacturing, ferrous metal smelting and calendaring, non-ferrous metal smelting and calendaring, general equipment manufacturing, special equipment manufacturing, and transportation equipment manufacturing. Other industries were defined as having low barriers to entry.

The degree to which trade liberalization impacts energy intensity is also related to the energy consumption and pollution discharge of the industry. If the industry in question is a low-pollution one, the energy consumption intensity is low, and the degree to which trade liberalization impacts its energy intensity is low. In contrast, if the said industry is a high-pollution one, the degree to which trade liberalization impacts its energy intensity is high. The classification criteria for pollution

\footnotetext{
(5) The proportion of state capital is expressed as the proportion of state capital in total capital in various industries. In 2015 , the average value of state capital proportion is $8.92 \%$.
} 
industries are based on the various industries' $\mathrm{CO}_{2}$ emission coefficients. This indicator is the product of the direct $\mathrm{CO}_{2}$ emission coefficient multiplied by the Leontief inverse matrix. Industries with values for this indicator that are higher than its average value for all industries were defined as high-pollution industries, whereas those with values for this indicator that are lower than its average value for all industries were defined as low-pollution industries. There were nine high-pollution industries: paper and paper products, petroleum processing and coking, chemical raw materials and chemical products manufacturing, chemical fiber manufacturing, rubber products manufacturing, non-metal mineral product manufacturing, ferrous metal smelting and calendaring, non-ferrous metal smelting and calendaring, and crafts and other manufacturing. Other industries were defined as low-pollution industries.

The first and second columns of Table 4 show the estimation results of how trade liberalization impacts energy intensity among industries with high barriers to entry and industries with low barriers to entry. The trade liberalization parameter values estimated for industries with low barriers to entry were larger than those of industries with high barriers to entry. The results show that trade liberalization plays a greater role in reducing energy intensity among industries with low barriers to entry. The third and fourth columns of Table 4 show the estimation results of how trade liberalization impacts energy intensity among high-pollution and low-pollution industries. The trade liberalization parameter values were significant for both types of industries. In terms of the degree of influence, trade liberalization plays a greater role in helping to reduce energy intensity among high-pollution industries than low-pollution industries. This is also consistent with the predictions.

Table4. Estimation results of heterogeneity testing

\begin{tabular}{ccccc}
\hline & $\begin{array}{c}\text { high barriers to } \\
\text { entry }\end{array}$ & $\begin{array}{c}\text { low barriers to } \\
\text { entry }\end{array}$ & high pollution & low pollution \\
\cline { 2 - 5 } & $(1)$ & $(2)$ & $(3)$ & $(4)$ \\
\hline Tariff & $0.4556^{* *}$ & $0.7838^{* *}$ & $0.9169^{* * *}$ & $0.6398^{* * *}$ \\
& $(2.38)$ & $(2.12)$ & $(4.00)$ & $(2.81)$ \\
ESTC & $1.1682^{* * *}$ & $0.9375^{* * *}$ & $0.9270^{* *}$ & $0.6035^{* *}$ \\
& $(4.70)$ & $(5.72)$ & $(4.12)$ & $(2.48)$ \\
Control variables & Yes & Yes & Yes & Yes \\
Industry fixed & Yes & Yes & Yes & Yes \\
effect & & & & \\
Time fixed effect & Yes & Yes & Yes & Yes \\
Observations & 216 & 270 & 162 & 324 \\
R-squared & 0.7454 & 0.7368 & 0.8412 & 0.7943 \\
\hline
\end{tabular}

Note: $(1) * * * \mathrm{p}<0.01,{ }^{* *} \mathrm{p}<0.05$, and ${ }^{*} \mathrm{p}<0.1 ;(2) \mathrm{t}$-values are reported in parentheses.

\subsection{Fuzzy Regression Discontinuity (FRD)}

The basic idea of the FRD is that energy intensity change may be caused by China's accession to the WTO if energy intensity jumps significantly in 2002. This paper first draws a graph of the relationship between energy intensity and running variable. As figure 3 shows, there is a significant jump of energy intensity in 2002. The result initially suggests that joining the WTO can reduce energy intensity in China. 


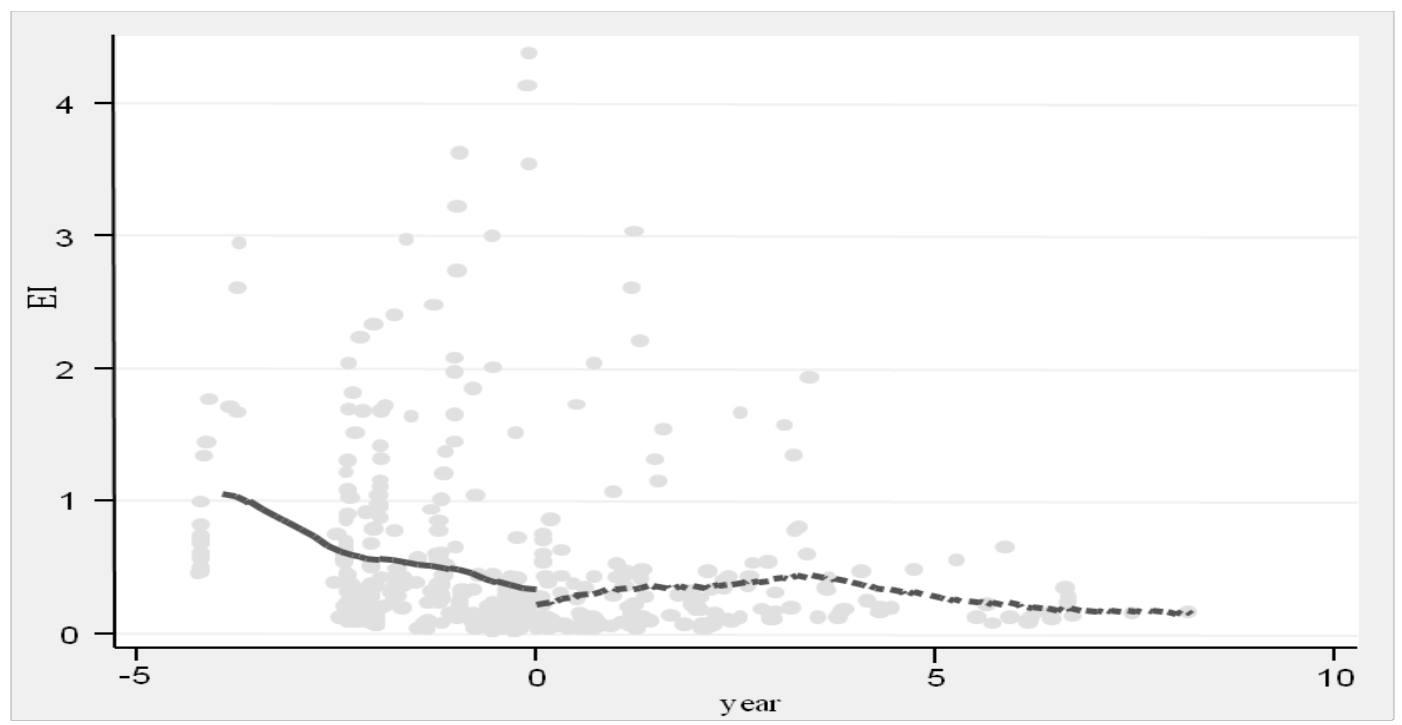

Fig 3. The relationship graph between energy intensity and running variable

Table 5 report the treatment effect of energy intensity after China entering WTO. When the covariables are added in turn, the estimation results do not affect the consistency of the FRD, but it can improve the estimation efficiency. From the estimation results, there is no significant change in the coefficient of treatment variable $\mathrm{D}$, regardless of whether or not covariables are added. The results reflect the robustness of the estimation. The results show that trade liberalization can significantly promote the reduction of energy intensity after China entering the WTO.

Table5. Estimation results of FRD

\begin{tabular}{|c|c|c|c|c|}
\hline & EI & EI & EI & EI \\
\hline & (1) & (2) & (3) & (4) \\
\hline \multirow[t]{2}{*}{$\mathrm{D}$} & $-0.7926 * * *$ & $-0.8118 * * *$ & $-0.9038^{*}$ & $-0.8615^{* *}$ \\
\hline & $(4.12)$ & $(3.36)$ & $(-1.87)$ & $(-2.24)$ \\
\hline \multirow[t]{2}{*}{$\mathrm{T}_{\mathrm{t}}-\mathrm{T}_{0}$} & $-0.0229 * * *$ & $-0.0199 * * *$ & $-0.0678 * *$ & $-0.0525^{* * *}$ \\
\hline & (3.34) & $(-4.00)$ & $(2.24)$ & (3.76) \\
\hline \multirow[t]{2}{*}{$\mathrm{D}\left(\mathrm{T}_{\mathrm{t}}-\mathrm{T}_{0}\right)$} & $0.1721^{* * *}$ & $0.1615^{* * *}$ & $0.2016^{* * *}$ & $0.2162 * * *$ \\
\hline & (7.79) & (7.15) & (5.39) & $(4.98)$ \\
\hline \multirow[t]{2}{*}{ ESTC } & & $0.6877^{* * *}$ & $1.2472 *$ & $0.9317 * *$ \\
\hline & & (2.94) & (1.93) & $(2.22)$ \\
\hline \multirow[t]{2}{*}{ lnScale } & & & $-0.0003 * * *$ & $-0.0003 * * *$ \\
\hline & & & $(-4.12)$ & $(-5.06)$ \\
\hline \multirow[t]{2}{*}{ ERI } & & & & $-0.8090 * *$ \\
\hline & & & & $(-2.16)$ \\
\hline R-squared & 0.4896 & 0.5203 & 0.5382 & 0.5769 \\
\hline Wald & 145.66 & 150.12 & 159.88 & 165.72 \\
\hline
\end{tabular}

Note: $(1) * * * p<0.01,{ }^{* *} \mathrm{p}<0.05$, and $* \mathrm{p}<0.1 ;(2) \mathrm{t}$-values are reported in parentheses.

\subsection{Testing for Robustness}

The paper will make the robust analysis of the above empirical results. Robust testing includes 
three aspects.

First, there may be endogenous problems. Although tariffs at the industry level are largely unaffected by economic, social and other factors within a country, the possibility of a two-way causality between tariffs and energy consumption is small. However, some important policy shocks (such as accession of FTA) may affect both tariffs and energy intensity, resulting in endogenous problems ${ }^{\circledR}$. This paper will perform instrumental variable regression in order to eliminate the endogeneity that may be present in trade liberalization variables (Gaston and Trefler, 1997; Beaulieu, 2000). Tariff rate promised by China in the tariff concession table (Annex 8: Schedule CLII) when its entry into the WTO is used as the instrumental variable of trade liberalization.

Second, we should considerate the impact from non-tariff barriers. Trade liberalization does not simply include lowered tariffs but also the reduction of various non-tariff barriers. However, the measurement indicators for non-tariff barriers are not standardized and are quite controversial. This paper adopts an indirect approach to studying non-tariff barriers. Among all of the industries, the textile industries experience the greatest reduction in non-tariff barriers. The impact from non-tariff barriers is eliminated after we exclude the textile industry and re-perform the regression process ( $\mathrm{Yu}$ and Liang, 2014).

Third, we should considerate potential measurement error problems. The re-measurement of energy intensity: Energy consumption per unit capital (EK) is used to measure energy intensity.

The first column of Table 6 shows the IV estimation results. The trade liberalization parameter values are positive and significant, and there are no significant changes to the coefficients of ordinary least squares (OLS) estimates. The second column shows the regression results after excluding the textile industry, whereas the third column shows the estimation results using energy consumption per unit capital as the independent variable. The finding that trade liberalization helps reduce energy intensity is robust.

Table6. Estimation results of endogenous and robustness tests

\begin{tabular}{cccc}
\hline & Endogenous & \multicolumn{2}{c}{ Robustness } \\
& IV & non-tariff barriers & energy intensity \\
\cline { 2 - 4 } & $(1)$ & $2.1933^{* * *}$ & $(3)$ \\
\hline Trade liberalization & $0.8762^{* * *}$ & $(4.88)$ & $4.7878^{* * *}$ \\
& $(6.23)$ & $1.0327^{* * *}$ & $(2.72)$ \\
ESTC & $0.6021^{* * *}$ & $(4.17)$ & $0.4438^{*}$ \\
& $(3.48)$ & Yes & $(1.77)$ \\
Control variables & Yes & Yes & Yes \\
Industry fixed effect & Yes & Yes & Yes \\
Time fixed effect & Yes & 468 & Yes \\
Observations & 486 & 0.7629 & 486 \\
R-squared & 0.7112 & & 0.7033 \\
\hline
\end{tabular}

Note: $(1){ }^{* * *} \mathrm{p}<0.01,{ }^{* *} \mathrm{p}<0.05$, and ${ }^{*} \mathrm{p}<0.1 ;$ (2) t-values are reported in parentheses.

\section{Research Conclusions}

Whether trade liberalization could result in excessive growth in energy consumption and

\footnotetext{
(6) FTA means Free Trade Agreements.
} 
pollution among developing countries is an issue of concern among many scholars. This paper studies the transmission mechanisms and effects of trade liberalization on energy intensity. This paper constructs panel data for 27 manufacturing industries in China over the period of 1994-2017, thereby conducting empirical tests through mediation models. The results find that trade liberalization significantly promotes the lowering of energy intensity, and trade liberalization promotes a decrease in energy intensity through ESTC. Heterogeneity test results show that the trade liberalization effect is higher in industries with low barriers to entry and high-pollution industries. Fuzzy Regression Discontinuity (FRD) results show that energy intensity decreasing as China's accession to the WTO (which is a breakpoint). The above results have passed the robust test and endogenous test.

The policy implications from the findings of this paper are as follows. Firstly, Chinese government should accelerate the reform to promote the trade liberalization. China should further open up for trading, lower trade barriers, and refine trade liberalization reforms. Meanwhile, China has to speed up the construction of the domestic market system and effectively link the domestic market with the international market. Secondly, China should vigorously improve the level of ESTC. ESTC has played a direct role in reducing energy intensity, improving energy efficiency and reducing pollution emissions. So, it also needs to actively bring in, assimilate, and absorb advanced foreign technologies, thereby realizing the dual goals of sustainable technological change and energy conservation and emissions reduction. Thirdly, Chinese government should reduce the energy intensity through various policy tools. On the one hand, the government should strengthen environmental regulations to restrict the introduction and expansion of high energy-consuming and highly polluting industries and phase out backward production capacity; on the other hand, local enterprises should be encouraged to import advanced energy-saving and environmental protection technologies and equipment. New energy industries and environmental protection industries should also be encouraged to invest in China.

\section{References}

Acemoglu, D. 2002. Directed technical change. The Review of Economic Studies 69(4): 781-809.

Alessandrini, M., B. Fattouh, B. Ferrarini, and P. Scaramozzino. 2011. Tariff liberalization and trade specialization: Lessons from India. Journal of Comparative Economics 39(4): 499-513.

Amiti, M., Konings, J., 2007, Trade liberalization, intermediate input, and productivity: Evidence from Indonesia, American Economic Review, 97(5): 1161-1638.

Antweiler, W., B. R. Copeland, and M. S. Taylor. 2001. Is free trade good for the environment? American Economic Review 91(4): 877-908.

Anwar, S., Sun, S., 2012, Trade liberalization, market competition and wage inequality in China's manufacturing sector, Economic Modelling, 29, 1268-1277.

Beaulieu, E. 2000. The Canada-U.S. free trade agreement and labour market adjustment in Canada. Canadian Journal of Economics 33(2): 540-563.

Beghin, J., and D. Roland-Holst. 1995. Trade liberalization and the environment in the Pacific Basin: Coordinated approaches to Mexican Trade and Environmental Policy. American Journal of Agriculture Economics 77(3): 778-785.

Betts, J. R. 1997. The skill bias of technological change in Canadian manufacturing industries. The Review of Economics and Statistics 79(1): 146-150.

Boucekkine, R., and A. Pommeret. 2004. Energy saving technical progress and capital stock: the 
role of embodiment. Economic Modelling 21(3): 429-444.

BÖhringer, C., Rutherford, T.F., Tarr, D.G., Turdyeva, 2015, Market structure and the environmental implications of trade liberalization: Russia's accession to the World Trade Organization, Review of International Economics, 23(5):897-923.

Burniaux, J. M., J. Martin, G. Nicoletti, and J. O. Martins. 1991. GREEN a multi-sector, multiregion general equilibrium models for quantifying the costs of curbing co emissions: A Technical Manual. Oecd Economics Department Working Papers.

Busse, M. 2004. Trade, environmental regulations and the World Trade Organization: New empirical Evidence. Journal of World Trade 30(2): 285-306.

Caselli, M., 2014, Trade, skill-biased technical change and wages in Mexican manufacturing, Applied Economics, 46(3), 336-348.

Cole, M. A., and R. J. R. Elliott. 2003. Determining the trade-environment composition effect: the role of capital, labor and environmental regulations. Journal of Environmental Economics and Management 46(3): 363-383.

Cole, M. A. 2006. Does trade liberalization increase national energy use?. Economics Letters 92(1): 108-112.

Copeland, B.R., Taylor, M.S., 2004, Trade, growth and the environment, Journal of Economic literature, 42: 7-71.

Grossman, G. M., and A. B. Krueger. 1995. Economic growth and the environment. The Quarterly Journal of Economics 110(2): 353-377.

Cutler, D.M., and A. Lleras-Muney. 2010. Understanding differences in health behaviors by education. Journal of Health Economics 29(1): 1-28.

Dessus, S., and M. Bussolo. 1998. Is there a trade-off between trade liberalization and pollution abatement? A computable general equilibrium assessment applied to Costa Rica. Journal of Policy Modeling 20(1): 11-31.

Ederington, J., A. Levinson, and J. Minier. 2004. Trade liberalization and pollution havens. Advances in Economic Analysis \& Policy 4(2): 1-20.

Eruygur, H. O. 2003. The skill biased technological change in Turkish manufacturing industries. MPRA Paper.

Fung, K. C., and A. M. Maechler. 2007. Trade liberalization and the environment: The case of intraindustry trade. Journal of International trade \& Economic Development 16(1): 53-69.

Gaston, N., and D. Trefler. 1997. The labour market consequences of the Canada-U.S. free trade agreement. Canadian Journal of Economics 30(1): 18-41.

Ghirmay, T., R. Grabowski, and S. C. Sharma. 2001. Exports, investment, efficiency and economic growth in LDC: an empirical investigation. Applied Economics 33(6): 689-700.

Ghani, G. M. 2012. Does trade liberalization effect energy consumption?. Energy Policy 43(2): 285290.

Gumilang, H., K. Mukhopadhyay, and P. Thomassin. 2011. Economic and environmental impacts of trade liberalization: The case of Indonesia. Economic Modeling 28(3): 1030-1041.

Hotelling, H. 1931. The Economics of Exhaustible Resources. The Journal of Political Economy 39(2): 137-175.

Hossain, MD.S., 2011, Panel estimation for $\mathrm{CO}_{2}$ emissions, energy consumption, economic growth, trade openness and urbanization of newly industrialized countries, Energy Policy, 39: 69916999. 
Hritonenko, N., and Y. Yatsenko. 2012. Energy substitutability and modernization of energyconsuming technologies. Energy Economics 34(5): 1548-1556.

Hunt, L. C. 1986. Energy and capital: substitutes or complements? A note on the importance of testing for non-neutral technical progress. Applied Economics 18(7): 729-735.

HÜbler, M., and A. Keller. 2010. Energy savings via FDI? Empirical evidence from developing countries. Environment and Development Economics 15(1): 59-80.

Karanfil, F., and Y. Y. Tamsamani. 2010. Is technological change biased toward energy? A multisectoral analysis for the French economy. Energy Policy 38(4): 1842-1850.

Kasman, A., Duman, Y.S., 2015, $\mathrm{CO}_{2}$ emissions, economic growth, energy consumption, trade and urbanization in new EU member and candidate countries: a panel data analysis, Economic Modelling, 44: 97-103.

Kemfert, C. 1998. Estimated substitution elasticities of a nested CES production function approach for Germany. Energy Economics 20(3): 249-264.

Klump, R., P. McAdam, and A. Willman. 2004. Factor substitution and factor-augmenting technical progress in the United States: A normalized supply-side system approach. Review of Economics and Statistics.

Koengkan, M., 2018, The positive impact of trade openness on consumption of energy: Fresh evidence from Andean community countries, Energy, 158: 936-943.

Lin, B., Abudu , H., 2019, Changes in energy intensity during the development process: evidence in Sub-Saharan Africa and policy implications, Energy, 183(15): 1012-1022.

Managi, S., Hibiki, A., Tsurumi, T., 2009, Does trade openness improve environmental quality? Journal of Economics and Management, 58: 346-363.

Michaels, G., Natraj, A., Van Reenen, J., 2010, Has ICT polarized skill demand? Evidence from eleven countries over 25 years, NBER working paper, No.16138.

Mielnik, O., and J. Goldemberg. 2002. Foreign direct investment and decoupling between energy and gross domestic product in developing countries. Energy Policy 30(2): 87-89.

Mitchener, K.J., Yan, S., 2010, Globalization, trade and wages: What does history tell us about China? NBER working paper, No. 15679.

Mukhopadhyay, K., D. Chakraborty, 2005, Is liberalization of trade good for the environment? Evidence from India, Asia-Pacific Development Journal, 12(1): 109-136.

Nasreen, S., Anwar, S., 2014, Causal relationship between trade openness, economic growth, and energy consumption: a panel data analysis of Asian countries, Energy Policy, 69: 82-91.

Newell, R., A. Jaffe, and R. Stavins. 1999. The induced innovation hypothesis and energy-saving technological change. Quarterly Journal of Economics 114(3): 941-975.

Perkins, R., Neumayer, E., 2005, The international diffusion of new technologies: a multitechnology analysis of latecomer advantage and global economic integration, Annals of the Association of American Geographers, 95(4): 789-808.

Popp, D. 2002. Induced innovation and energy prices. American Economics Review 92(1): 160-180.

Rafiq, S., Salim, R., Nielsen, I., 2016, Urbanization, openness, emissions, and energy intensity: A study of increasingly urbanized emerging economics, Energy Economics, 56: 20-28.

Sadorsky, P., 2011, Trade and energy consumption in the Middle East, Energy Economics, 33: 739749.

Sbia, R., Shahbaz, M., Hamdi, H., 2014, A contribution of foreign direct investment, clean energy, trade openness, carbon emissions and economic growth to energy demand in UAE, Economic 
Modelling, 36: 191-197.

Shahbaz, M., Tiwari, A.K., Nasir, M., 2013, The effects of financial development, economic growth, coal consumption and trade openness on $\mathrm{CO}_{2}$ emission in South Africa, Energy Policy, 61: 1452-1459.

Shafiei, S., Salim, R.A., 2014, Non-renewable and renewable energy consumption and $\mathrm{CO}_{2}$ emissions in OECD countries: a comparative analysis, Energy Policy, 66: 547-556.

Shen, J. 2008. Trade liberalization and environmental degradation in China. Applied Economics 40(8): 997-1004.

Stern, D.I., 2007, The effect of NAFTA on energy and environmental efficiency in Mexico, The Policy Studies Journal, 35(2): 291-323.

Wang, J., 2020, Will entrepreneurship promote productivity growth in China? China \& World Economy, 28(3): 73-89.

Xu, X. M., and X. P. Yin. 2016. Trade Openness, Exports and Energy Consumption in China:A Study Based on Provincial Panel Data from 2000 to 2013. International Business (03): 5-14.

Yu, M. J., and Z. H. Liang. 2014. Trade liberalization and labor income share in China: An Empirical Analysis Based on the data of manufacturing trade enterprises. Management World (07): 2231.

Zhang, Y. G. 2009. Impact of Trade on China's Energy Consumption and SO2

Emission :1987 2006. The Journal of Quantitative \& Technical Economics 26 (01): 16-30.

Zon, A., and I. H. Yetkiner. 2003. An endogenous growth model with embodied energy-saving technical change. Resource and Energy Economics 25(1): 81-103. 